\title{
Air concentrations of volatile compounds near oil and gas production: a community-based exploratory study
}

\author{
Gregg P Macey ${ }^{1}$, Ruth Breech², Mark Chernaik ${ }^{3}$, Caroline Cox ${ }^{4}$, Denny Larson², Deb Thomas ${ }^{5}$ \\ and David O Carpenter ${ }^{6 *}$
}

\begin{abstract}
Background: Horizontal drilling, hydraulic fracturing, and other drilling and well stimulation technologies are now used widely in the United States and increasingly in other countries. They enable increases in oil and gas production, but there has been inadequate attention to human health impacts. Air quality near oil and gas operations is an underexplored human health concern for five reasons: (1) prior focus on threats to water quality; (2) an evolving understanding of contributions of certain oil and gas production processes to air quality; (3) limited state air quality monitoring networks; (4) significant variability in air emissions and concentrations; and (5) air quality research that misses impacts important to residents. Preliminary research suggests that volatile compounds, including hazardous air pollutants, are of potential concern. This study differs from prior research in its use of a community-based process to identify sampling locations. Through this approach, we determine concentrations of volatile compounds in air near operations that reflect community concerns and point to the need for more fine-grained and frequent monitoring at points along the production life cycle.

Methods: Grab and passive air samples were collected by trained volunteers at locations identified through systematic observation of industrial operations and air impacts over the course of resident daily routines. A total of 75 volatile organics were measured using EPA Method TO-15 or TO-3 by gas chromatography/mass spectrometry. Formaldehyde levels were determined using UMEx 100 Passive Samplers.
\end{abstract}

Results: Levels of eight volatile chemicals exceeded federal guidelines under several operational circumstances. Benzene, formaldehyde, and hydrogen sulfide were the most common compounds to exceed acute and other health-based risk levels.

Conclusions: Air concentrations of potentially dangerous compounds and chemical mixtures are frequently present near oil and gas production sites. Community-based research can provide an important supplement to state air quality monitoring programs.

Keywords: Benzene, Community monitoring, Formaldehyde, Grab and passive samples, Hydraulic fracturing, Hydrogen sulfide, Oil and gas

\footnotetext{
* Correspondence: dcarpenter@albany.edu

${ }^{6}$ Institute for Health and the Environment, University at Albany, Rensselaer, New York, USA

Full list of author information is available at the end of the article
} 


\section{Background}

New drilling and well stimulation technologies have led to dramatic shifts in the energy market. The Energy Information Administration forecasts that by the 2030s, the United States will become a net exporter of petroleum liquids such as shale oil [1]. Already an exporter of natural gas, the U.S. will retrieve nearly half of its gas from shale formations by that time [2]. Reserves such as shale oil and gas are referred to as "unconventional" because fuels within them do not readily flow to the surface [3]. Instead, they are distributed among tight sandstone, shale, and other geologic strata. Intensive practices are used to retrieve them, such as directional drilling (many kilometres underground and one or more kilometres horizontally through a formation) and hydraulic fracturing to break up the formation and ensure movement through source rock (using millions of gallons of water mixed with chemicals and sand, or "proppants") [4]. These technologies present public health challenges, including threats to air quality [5-7].

Unconventional oil and gas (hereinafter "UOG") development and production involve multiple sources of physical stressors (e.g., noise, light, and vibrations) [6], toxicants (e.g., benzene, constituents in drilling and hydraulic fracturing fluids) [8], and radiological materials (e.g., technologically-enhanced, naturally-occurring radioactive material) [9], including air emissions [10,11]. Air quality near UOG sites is an underexplored human health concern for several reasons. For a time, environmental scientists and regulators were primarily interested in potential impacts to surface and groundwater quality. Highprofile impacts and the subsurface nature of technologies (e.g., hydraulic fracturing) encouraged this research trajectory [12]. This was true despite the fact that UOG development brings to the surface, in the case of natural gas, methane $(78.3 \%)$, non-methane hydrocarbons (17.8\%), nitrogen (1.8\%), carbon dioxide (1.5\%), and hydrogen sulfide $(0.5 \%)$ [13]. These constituents, as well as emissions from combustion processes at the surface, are released to the air throughout the life cycle of a productive well [14].

Air emissions from UOG operations have been generally understood for some time - volatile organic compounds (VOCs), polycyclic aromatic hydrocarbons (PAHs), and criteria air pollutants such as NOx and $\mathrm{PM}_{2.5}$ can be released at the wellhead, in controlled burns (flaring), from produced water storage pits and tanks, and by diesel-powered equipment and trucks, among other sources [15]. Yet the full range of emissions from drilling, well completion, and other activities remains elusive. New source categories are discovered, emissions from life cycle stages such as transmission and well abandonment have yet to be determined, and even stages such as drilling continue to present uncertainty [16]. We do not understand the extent of drilling-related air emissions as pockets of methane, propane, and other constituents in the subsurface are disturbed and released to the atmosphere [17]. Emissions measurements during flowback vary by orders of magnitude [18]. These and other data gaps limit the accuracy of state and federal emissions inventories, which compile and track known emissions sources. Inventories are also limited by selfreporting and data collection, and rely in some cases on outmoded emissions factors [15]. Flawed inventories constrain human health risk assessment and other research [7] and slow the identification of phenomena such as photochemical ozone production during winter months [19].

State pollution monitoring networks also constrain research on the air impacts of UOG development. Historically, air quality monitoring targeted urban areas, and criteria air pollutants such as particulate matter and ozone precursors were the primary chemicals of concern [10]. Monitoring stations were designed to ensure compliance with National Ambient Air Quality Standards (NAAQS) for a half-dozen pollutants. Even networks that focus on oil and gas emissions, such as one operated by public health officials in Garfield County, Colorado, do not target individual well pads. The Garfield County network encompasses five sites to monitor a suite of VOCs and (at three sites) particulate matter, in a jurisdiction that covers nearly 3,000 square miles of complex terrain [20]. The Texas Commission on Environmental Quality has arguably the most extensive monitoring network for UOG air emissions in oil and gas regions. Its monitors were sited to minimize urban source impacts and target locations where the public might be exposed to air emissions [21]. Still, its networks can be sparse; there are five permanent monitoring stations in the Eagle Ford Shale region, where 7,000 oil and gas wells have been drilled since 2008 [22]. These and other limited networks potentially mask local hot spots, the effects of unique topography, and fugitive emissions at certain well pads.

Even a denser monitoring network taking continuous samples may be unable to capture the full range of air impacts of UOG operations. Sources of variability of air emissions and concentrations of VOCs and other pollutants near UOG sites include: (1) the spatial variability of UOG operations; (2) the discontinuous use of equipment such as diesel trucks, glycol dehydrators, separators, and compressors during preparation, drilling, hydraulic fracturing, well completion, and other stages; (3) the composition of shale and other formations and the specific constituents of the drilling and hydraulic fracturing fluids used on-site (which can influence the makeup of produced or flowback water stored in pits and tanks); (4) intermittent emissions from venting, flaring, and leaks; (5) the shifting location, spacing, and intensity of well pads in response to market conditions, 
improvements in technology, and regulatory changes; (6) the effects of wind, complex terrain, and microclimates; and (7) considerable differences among states in permitting, leak detection and repair, and other requirements [10,16,23-25]. Wind, for example, can influence outdoor and indoor concentrations of air pollutants. Brown et al. found that local air movement and mixing depth contribute to peak exposure to VOCs one mile from a compressor station [25]. Colborn et al. noted the role of wind and topography in higher VOC concentrations during winter months, when inversions trap air near ground level [10]. Fuller et al. identified wind speed and wind direction as significant predictors of indoor particulate matter levels near highways [26]. Similar variation can be found within and across geologic formations. Unconventional wells in the Barnett Shale play, for example, differ considerably in terms of reservoir quality, production rates, and recoverable gas [27]. Domestic shale gas plays exhibit even greater diversity, including depth and thickness of recoverable resources, the amount and range of chemicals present in produced water, and the presence of constituents such as bromide, naturally occurring radioactive material, hydrogen sulfide, and other toxic elements [23,28].

These and other sources of variability, and the adaptive drilling and well completion techniques they encourage, complicate the design of setback and well spacing rules that are protective of the public. They also explain why air quality studies carried out in UOG regions yield conflicting results. For example, McKenzie et al. [11] found greater cumulative cancer risks and higher non-cancer hazard indices for residents living less than 0.5 miles from certain well pads in Colorado, while Bunch et al. [21] analyzed data from monitors focused on regional atmospheric concentrations in the Barnett Shale region and found no exceedance of health-based comparison values. Colborn et al. [10] gathered weekly, 24-hour samples 0.7 miles from a well pad in Garfield County, and noted a "great deal of variability across sampling dates in the numbers and concentrations of chemicals detected." Eapi et al. [29] found substantial variation in fenceline concentrations of methane and hydrogen sulfide, which could not be explained by production volume, number of wells, or condensate volume at natural gas development sites.

Institutional factors also influence research on ambient air quality near UOG sites. Congressional exemption of oil and gas operations from provisions of the Clean Air Act, Clean Water Act, Safe Drinking Water Act, Emergency Planning and Community Right-to-Know Act, and other statutes limits data collection on the impacts of oil and gas development [30,31]. In addition, the peer-reviewed literature is divided between "top-down" and "bottom-up" treatments of air quality. The first set of studies explores the impact of UOG operations on regional air quality, with a concern for methane emissions and ozone precursors in regions such as the Green River Basin in Wyoming [32], the Uintah Basin in northeastern Utah [33], and the DenverJulesburg Basin, home of the Wattenberg Field in northeastern Colorado [34]. These studies rely on airborne and tower measurements, and are at times supplemented by ground measurements such as mobile monitoring.

For example, Petron et al. [35] found a strong alkane signature downwind from the Denver-Julesburg Basin, based on samples taken at a 300-m tall tower (the National Oceanic and Atmospheric Administration Boulder Atmospheric Observatory) and a mobile monitoring unit. In the Uintah Basin, where winter ozone levels exceeded the NAAQS 68 times in 2010, Helmig et al. [36] carried out vertical profiling of ozone precursors at a tower at the northern edge of a gas field. They found levels of atmospheric alkanes during temperature inversion events in 2013 that were 200-300 times greater than regional background. These and other "top-down" studies are also used to estimate methane leakage, which is helpful in comparing the climate-forcing impact of UOG to the use of coal-fired power plants. Loss rate estimates for methane and other hydrocarbons vary considerably by study, from 17\% [37] (Los Angeles Basin) to 8.9\% [38] (Uintah Basin) (6.2-11.7\%, 95\% C.I.) to 4\% [35] (Denver-Julesburg Basin) (2.3-7.7\%, 95\% C.I.). A number of studies share the finding that EPA underestimates methane leakage rates across the life cycle (their estimate was $1.65 \%$ in 2013) [16], but others, extrapolating from emissions factors and/or direct measurement, produce estimates as low as $0.42 \%$ [18]. None of these studies attempts to characterize air concentrations within residential or publicly-accessible areas near UOG operations.

Other studies follow a "bottom-up" approach to air quality, which is limited by access to well pads and other infrastructure, the availability of a power source for monitoring equipment, the stage of operation underway, scheduled or unscheduled flashing, flaring, and fugitive releases, or movement of truck traffic and equipment at or near a well pad during a given sampling period. Thus, bottom-up studies vary in terms of distance to site, sample frequency, and chemicals targeted. This helps explain the range of findings in the published literature. Nevertheless, existing research gives support to resident reports of acute and long-term health symptoms and other reductions in quality of life. Even as they offer conflicting evidence of the relative importance of one stage of production or another to air emissions $[10,11]$, or differ in their ultimate conclusion regarding the existence $[10,11,14,35,36,39]$ or lack $[21,40,41]$ of human health threats from air emissions, they find VOC concentrations in ambient air considerable distances from well pads, including in residential areas and public spaces. 
The research questions that guide existing studies create a final barrier to our ability to characterize air emissions in UOG regions. Top-down studies are motivated by questions such as identifying sources of regional nonattainment of ozone standards, or estimating methane and other hydrocarbon leakage rates from UOG operations. Bottom-up research gathers data from one or a limited number of well pads, chosen for reasons such as access or cooperation by owners and operators. The data are used to discuss general exposure conditions for an oftenhypothetical community, or used to derive a risk factor. In either mode of study, resident exposure does not directly motivate the sampling protocol. Rather, it is considered obliquely in a study's choice of sample location (e.g., a one that is "near a small community"), assumed in measurements of concentrations within a certain distance of UOG activity, or ignored. What are missing from these studies are protocols grounded in a community's experience of air quality impacts of UOG operations.

Our multi-state air quality monitoring study uses a community-based, participatory research (CBPR) design to explore conditions near UOG operations [42]. Its sampling protocol is based not on access to a well pad, data needs conditioned by an existing averaging standard, or regional policy concerns. Rather, we partnered with residents in UOG regions to measure air quality under circumstances that, given local knowledge of operations (e.g., emissions from particular equipment or intermittent practices) gained through daily routines (e.g., regular observation of well pads) and use of public and private spaces nearby (e.g., livestock movement, farming) were viewed by community members as potential threats to human health. Existing studies often lack a data set suitable for statistical analysis. When such analyses are occasionally imposed on bottom-up data sets, they explain only a fraction of the variance in air quality outcomes. For example, the highest $\mathrm{R}^{2}$ values in a study of 66 sites, which, due to the study's broad spatial range was limited to measurements of methane and hydrogen sulfide, were $0.26\left(\mathrm{H}_{2} \mathrm{~S}\right.$ concentration vs. condensate volume nearby) and $0.17\left(\mathrm{H}_{2} \mathrm{~S}\right.$ and number of wells nearby) [29]. CBPR studies, by comparison, are place-based they begin with the experience of a population in order to identify environmental stressors and explore the heterogeneity of circumstances under which they arise $[43,44]$. Rather than discount these circumstances for lack of statistical power, they can be used to define the scope of confirmatory studies, tailor air quality monitoring networks and studies, or suggest novel pollution control measures and best management practices.

\section{Methods}

We explore air quality at a previously neglected scale: near a range of UOG development and production sites that are the focus of community concern. Residents conducted sampling in response to operational conditions, odor events, and a history of the onset of acute symptoms. Residents selected sampling sites after they completed a training program run by Global Community Monitor (GCM), an organization that has developed and modified community-based sampling protocols for more than twenty years. Sampling is designed to obtain accurate readings of public exposure near UOG development in the part-per-billion range [45]. Training sessions followed a written manual on proper sampling protocol and included instruction by experienced members of GCM in a classroom setting for five hours. In addition, samplers were trained in the field to properly demonstrate Quality Assurance/Quality Control (QA/QC) methods, such as use of data sheets and chain of custody records, sampling procedures including not taking samples in the presence of vehicle traffic or other sources of VOCs, and protocols for storage and delivery to an analytic laboratory [45]. Chain of Custody forms provided by the laboratory were explained and filled out in exercises in which each sampler participated. The trainings for community-based air sampling and related QA/QC measures were developed in conjunction with the Environmental Protection Agency under the federal Environmental Monitoring for Public Access and Community Tracking (EMPACT) program, and refined in cooperation with agencies including the Health Services Department of Contra Costa County, California and the Delaware Department of Natural Resources [46,47]. Any sample that did not meet QA/QC criteria was not included in the final data set.

Community monitors gauged industrial activity using field log sheets ("pollution logs") that allow each resident to record what they see, hear, feel, smell, and taste in areas downwind of industrial activity as they go about their daily routines. Each community monitor participated voluntarily in data collection for this study. They provided consent to use data gathered with questionnaires that they co-designed as well as grab and passive samplers. Residents documented activity including: (a) visible emissions drifting off-site; (b) odors that appear to derive from a site; (c) acute health symptoms that occur while in proximity to a site or during a specific industrial activity; (d) audible sounds of particular equipment in use within the boundaries of an operating well pad or related infrastructure; and (e) visible activity onsite, including the number and types of heavy trucks and tanks, vehicle traffic, workers present and job categories, and physical changes such as noise and vibrations near certain equipment. Similar to a neighborhood police watch, each resident determined locations that they would continue to observe and potentially return to for sampling.

Sampling for volatile compounds other than formaldehyde was carried out using methods described in 
O'Rourke and Macey [48] and Larson et al. [49] using an evacuated sampling ("bucket") vessel modelled after the Summa canister [50]. The bucket is inexpensive, portable, and consists of a 10-liter Tedlar bag and vacuum to take a grab sample of air for two to three minutes (Figure 1). Air is collected using a batteryoperated pump that forces air out of the bucket. Negative pressure created inside the sealed bucket by the external vacuum pump opens the bag when a stainless steel bulkhead is opened. After taking the sample, the Tedlar bag is sealed and sent to an analytical laboratory. The bucket sampler operates on the same principle that Summa canisters employ. Rather than collect a sample in a stainless steel can, the bucket contains a special bag made of Tedlar to hold the sample. Bags are obtained from the laboratory that processes the sample and purged three times with pure nitrogen by the laboratory prior to use. GCM's founder developed the sampling program under a project for Communities for a Better Environment, a non-profit organization founded in 1978 that provides legal, scientific, and technical assistance to heavily polluted communities. The device has been subjected to numerous validation tests organized by government agencies and independent laboratories [51-54].
Refinements include the use of field duplicates, which demonstrate no significant variation in results across comparison studies [45].

Residents collected 35 grab samples at locations of community concern, under conditions that would lead them to register a complaint with relevant authorities such as a county public health department or state oil and gas commission. Health symptoms contributed to the decision to take a grab sample on 29 occasions. The most common symptoms reported by samplers were headaches (17 reports), dizziness or light-headedness (13 reports), irritated, burning, or running nose (12 reports), nausea (11 reports), and sore or irritated throat (11 reports). Further details regarding each sample are provided in Additional file 1 (Tables S1 through S5).

In addition to grab samples, 41 formaldehyde badges were deployed in the five states targeting production facilities and compressor stations based on the results of pollution patrols. UMEx100 Passive Samplers for Formaldehyde are manufactured by SKC Inc. Samplers were placed near operating compressor stations and production facilities for a minimum of eight hours.

Samples were ultimately collected near production pads, compressor stations, condensate tank farms, gas

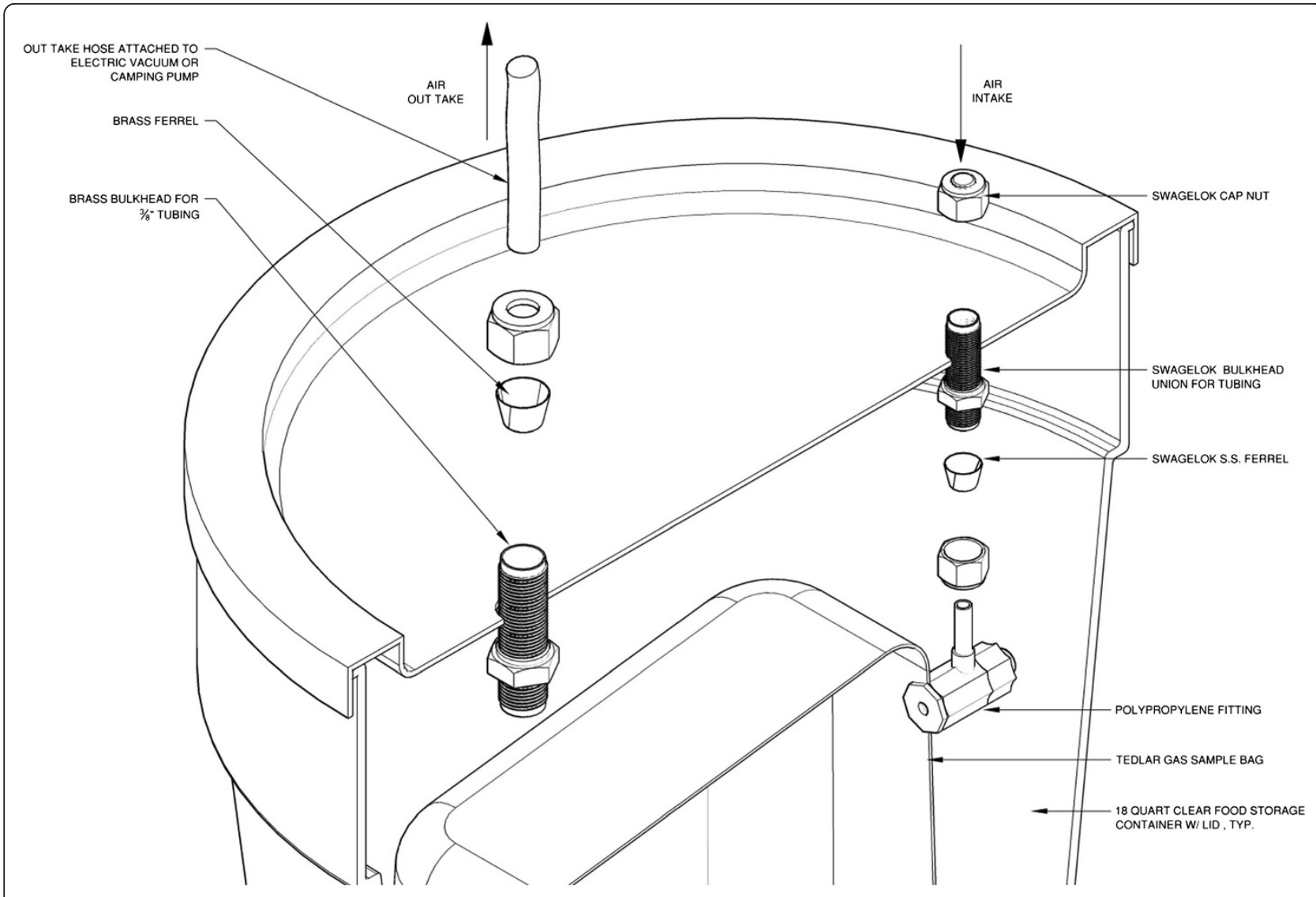

Figure 1 Design of bucket grab sampling device. 
processing stations, and wastewater and produced water impoundments in five states (Arkansas, Colorado, Ohio, Pennsylvania, and Wyoming). The states were chosen to reflect a diverse range of urban and rural communities, operations (e.g., number of wells permitted and developed), history of development, and stages of production (see Table 1).

Air samples were analyzed for 75 volatile organic compounds (VOCs), including benzene, ethylbenzene, acrylonitrile, methylene chloride, toluene, hexane, heptane, and xylene by ALS Laboratories (Simi Valley, CA 93065) using EPA Method TO-15 or TO-3 (methane) by gas chromatograph/mass spectrometer interface to a whole air preconcentrator. Formaldehyde samples were analyzed using EPA Method TO-11A, modified for the sampling device by high performance liquid chromatography with UV detection. Samples were also analyzed for 20 sulfur compounds by ASTM D 5504-08 using a gas chromatograph equipped with a sulfur chemiluminescence detector. All compounds with the exception of hydrogen sulfide and carbonyl sulfide were quantitated against the initial calibration curve for methyl mercaptan. Chemicals of concern were compared to U.S. Agency for Toxic Substances and Disease Registry (ATSDR) minimal risk levels (MRLs) and EPA Integrated Risk Information System (IRIS) cancer risk levels. MRLs are estimates of daily human exposure that can occur without appreciable risk of human health effects. They are derived for acute (1-14 days), intermediate (15-364 days), or chronic (365 days or longer) periods of exposure. The laboratory is certified by ten state departments of health or environment, the American Industrial Hygiene Association, and the U.S. Department of Defense.

\section{Results}

Table 1 shows the diverse range of operation, including number of wells permitted and developed and setbacks from housing and other occupied structures, in UOG regions where grab and passive air samples were collected through partnership with community-based organizations.

\section{Air contaminants}

We identified unique chemical mixtures at each sample location (see Tables S1 through S5 in Additional file 1). In addition, we identified eight volatile compounds at concentrations that exceeded ATSDR minimal risk levels (MRLs) or EPA Integrated Risk Information System (IRIS) cancer risk levels (see Table 2). Although our samples represent a single point in time, we compared concentrations to acute as well as chronic risk levels as many of the activities that generate volatile compounds near UOG operations are long-duration (the life cycle of an unconventional natural gas well can span several decades) [16]. Residents chose sample locations where odors and symptoms were the "norm" for the area, not a one-time event. In addition, a growing body of research suggests that peak (e.g., 1-hr. maximum), rather than average exposure to air emissions may better capture certain risks to human health [55-57].

Sixteen of the 35 grab samples, and 14 of the 41 passive samples, had concentrations of volatiles that exceeded ATSDR and/or EPA IRIS levels. ATSDR MRLs and EPA IRIS levels for chemicals of concern are provided in Table 2. The chemicals that most commonly exceeded these levels were hydrogen sulfide, formaldehyde, and benzene. Background levels for these chemicals are $0.15 \mu \mathrm{g} / \mathrm{m}^{3}$ for hydrogen sulfide, $0.25 \mu \mathrm{g} / \mathrm{m}^{3}$ for formaldehyde, and $0.15 \mu \mathrm{g} / \mathrm{m}^{3}$ for benzene [58-60]. Our samples that exceeded health-based risk levels were 90-66,000x background levels for hydrogen sulfide, 30-240× background levels for formaldehyde, and 35-770,000× background levels for benzene. Details of our results are presented in Tables 3, 4, and 5 and in Figures 2, 3, and 4 (greater detail is provided in Additional file 1). A stateby-state summary follows.

\section{Wyoming (Park County)}

Nine of the ten grab samples contained volatiles above ATSDR MRLs or EPA IRIS risk levels. Seven contained high concentrations of hydrogen sulfide (one was over $600 \times$ the ATSDR acute MRL) and three contained high levels of benzene, including one over $12,000 \times$ the ATSDR acute MRL. The sample with the highest benzene concentrations also contained 480,000 micrograms per cubic meter of heptane, 3,100,000 micrograms per cubic meter of pentane, and 4,100,000 micrograms per cubic meter of butane, all hydrocarbons that are frequently associated with methane. These hydrocarbon concentrations exceeded occupational health standards (NIOSH recommended exposure limits). Four of the seven samples with high levels of hydrogen sulfide were taken in northeast Park County (near Deaver), and three of the four samples with high benzene levels were taken in northwest Park County (near Clark). One of the five passive samples contained formaldehyde at levels that exceeded ATSDR MRLs and the 1/10,000 cancer risk level (Table 3, Figure 2).

\section{Wyoming (Fremont County)}

Four of the five grab samples contained volatiles at concentrations that exceeded ATSDR MRLs or EPA IRIS risk levels. One sample contained six volatiles exceeding these levels, including benzene at $75 \times$ the ATSDR acute MRL and $22 \times$ the EPA IRIS 1/10,000 cancer risk level. A second sample contained three volatiles exceeding ATSDR or EPA IRIS levels and also contained 4,167,000 micrograms per cubic meter of methane, an amount that exceeds its occupational health standard (Threshold Limit Value). None of the passive samples contained 
Table 1 Oil and gas operations by state

\begin{tabular}{|c|c|c|c|c|c|c|c|}
\hline \multirow[b]{2}{*}{ State } & \multirow{2}{*}{$\begin{array}{l}\text { Drilling permits } \\
\text { issued (year) }\end{array}$} & \multicolumn{2}{|r|}{ Wells } & \multicolumn{2}{|c|}{ Production } & \multirow{2}{*}{$\begin{array}{c}\text { Setback requirements } \\
\text { (dwellings and occupied structures) }\end{array}$} & \multirow{2}{*}{$\begin{array}{l}\text { Ambient air quality } \\
\text { standards }\end{array}$} \\
\hline & & $\begin{array}{l}\text { Drilled } \\
\text { (year) }\end{array}$ & $\begin{array}{l}\text { Producing } \\
\text { (year) }\end{array}$ & $\begin{array}{c}\text { Gas }(T c f) \\
\text { (year) }\end{array}$ & $\begin{array}{l}\text { Oil (MMbbl) } \\
\quad \text { (year) }\end{array}$ & & \\
\hline \multirow[t]{2}{*}{$A R$} & $\sim 890(2012)^{a}$ & - & 8,538 (gas) $(2012)^{b}$ & $1.15(2012)^{b}$ & $6.59(2012)^{a}$ & $200 \mathrm{ft}$. (from produced fluids storage tanks to habitable dwelling) & 20 ppm (5 min.); 80 ppb (8-hr.) $\left(\mathrm{H}_{2} \mathrm{~S}\right)^{\mathrm{c}}$ \\
\hline & $\sim 1,090(2011)^{a}$ & & & & & $\begin{array}{l}300 \mathrm{ft} \text {. (from produced fluids storage tanks to school, } \\
\text { hospital, or other public use building) }\end{array}$ & \\
\hline \multirow[t]{2}{*}{$\mathrm{CO}$} & $4,025(2013)^{a}$ & - & $46,697(2014)^{d}$ & $1.71(2012)^{b}$ & $64.88(2013)^{a}$ & $500 \mathrm{ft}$. (from well to home or building, absent waiver) & $-c^{c, e}$ \\
\hline & $3,775(2012)^{a}$ & & & & & $\begin{array}{l}1,000 \mathrm{ft} \text {. (from well to high occupancy building, } \\
\text { absent hearing and approval) }\end{array}$ & \\
\hline \multirow[t]{3}{*}{$\mathrm{OH}$} & $903(2012)^{a}$ & $553(2012)^{a}$ & $51,739(2012)^{a}$ & $.084(2012)^{b}$ & $4.97(2012)^{a}$ & $\begin{array}{l}150 \mathrm{ft} \text {. (occupied dwelling in urbanized area, } \\
\text { absent consent) }\end{array}$ & $-c_{\text {, e }}$ \\
\hline & $690(2011)^{a}$ & & & & & $150 \mathrm{ft}$. (occupied or public dwelling, non-urban area) & \\
\hline & & & & & & $\begin{array}{l}200 \mathrm{ft} \text {. (occupied dwelling w/in drilling unit } \\
\text { due to mandatory pooling) }\end{array}$ & \\
\hline \multirow[t]{2}{*}{ PA } & $4,617(2013)^{\mathrm{a}}$ & $2,174(2013)^{a}$ & $55,812(2011)^{f}$ & $2.26(2012)^{b}$ & $2.7(2011)^{\mathrm{a}}$ & $500 \mathrm{ft}$. (from well bore to building or water well) & 0.1 ppm (1-hr.); 0.005 ppm \\
\hline & $4,090(2012)^{a}$ & & & & & & \\
\hline WY & 3,230 (Sept. 2013-Aug. 2014) & - & $37,301(2012)^{a}$ & $2.23(2012)^{b}$ & $57.5(2012)^{a}$ & $\begin{array}{l}350 \mathrm{ft} \text {. (from wellhead, pumping unit, pit, } \\
\text { production tank, and/or production equipment } \\
\text { to residence, school, or hospital) }\end{array}$ & $\begin{array}{l}40 \mu \mathrm{\mu g} / \mathrm{m}^{3} \text { (half-hr. ave., } \\
2 \times \mathrm{w} / \mathrm{in} 5 \text { days) }\left(\mathrm{H}_{2} \mathrm{~S}\right)^{\mathrm{c}, \mathrm{e}}\end{array}$ \\
\hline 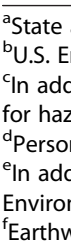 & $\begin{array}{l}\text { agency data. } \\
\text { nergy Information Administratio } \\
\text { lition to National Ambient Air Q } \\
\text { ardous air pollutants ( } 40 \text { C.F.R. § } \\
\text { nal communication with state as } \\
\text { lition to state emissions standar } \\
\text { hment's revised Air Quality Contr } \\
\text { vorks data. }\end{array}$ & $\begin{array}{l}\text { In data. } \\
\text { uality Standards } \\
\$ \$ 63.760-63.77 \\
\text { gency. } \\
\text { ds (e.g., vOC em } \\
\text { rol Commission }\end{array}$ & $\begin{array}{l}\text { s for criteria air polluta } \\
\text { 77) - applicable to the } \\
\text { nissions from glycol de } \\
\text { Regulation Numbers }\end{array}$ & $\begin{array}{l}\text { ints and federal } \\
\text { oil and gas in } \\
\text { ehydrators; gre } \\
3,6 \text {, and } 7 \text { (adc }\end{array}$ & $\begin{array}{l}\text { al emissions stan } \\
\text { idustry. } \\
\text { op completions; } 23 \text { Februa }\end{array}$ & $\begin{array}{l}\text { Idards - new source performance standards ( } 40 \text { C.F.R. } \S \S 60.5360-60.543 \\
\text { valve requirements for pneumatic devices). See, for example, Colorado } \\
\text { ary 2014). }\end{array}$ & 30) and national emission standards \\
\hline
\end{tabular}


Table 2 ATSDR minimal risk levels and EPA IRIS cancer risk levels for chemicals of concern (all data in $\mu \mathrm{g} / \mathrm{m}^{3}$ )

\begin{tabular}{|c|c|c|c|c|c|c|}
\hline \multirow[t]{2}{*}{ Chemical } & \multicolumn{3}{|c|}{ ATSDR MRLs } & \multicolumn{3}{|c|}{ IRIS cancer risk levels } \\
\hline & Acute & Intermediate & Chronic & $1 / 1,000,000$ & $1 / 100,000$ & $1 / 10,000$ \\
\hline Benzene & 29 & 20 & 10 & .45 & 4.5 & 45 \\
\hline 1,3 butadiene & & & & 0.03 & 0.3 & 3 \\
\hline Ethylbenzene & 21,700 & 8,680 & 260 & & & \\
\hline Formaldehyde & 49 & 37 & 10 & 0.08 & 0.8 & 8 \\
\hline N-hexane & & & 2,115 & & & \\
\hline Hydrogen sulfide & 98 & 28 & & & & \\
\hline Toluene & 3,750 & & 300 & & & \\
\hline Xylenes & 8,680 & 2,604 & 217 & & & \\
\hline
\end{tabular}

Table 3 Concentrations of volatile compounds exceeding health-based risk levels in samples collected in Wyoming

\begin{tabular}{|c|c|c|c|c|c|c|}
\hline State/ID & County & Nearest infrastructure & Chemical & $\begin{array}{c}\text { Concentration } \\
\left(\mu \mathrm{g} / \mathrm{m}^{3}\right)\end{array}$ & $\begin{array}{l}\text { ATSDR MRLs } \\
\text { exceeded }\end{array}$ & $\begin{array}{l}\text { EPA IRIS cancer } \\
\text { risk exceeded }\end{array}$ \\
\hline WY-4586 & Fremont & $5 \mathrm{~m}$ from separator & Hydrogen sulfide & 590 & $\mathrm{I}, \mathrm{A}$ & $\mathrm{n} / \mathrm{a}$ \\
\hline WY-4586 & Fremont & $5 \mathrm{~m}$ from separator & Benzene & 2,200 & $C, I, A$ & $1 / 10,000$ \\
\hline WY-4586 & Fremont & $5 \mathrm{~m}$ from separator & Toluene & 1,400 & C & $\mathrm{n} / \mathrm{a}$ \\
\hline$W Y-4586$ & Fremont & $5 \mathrm{~m}$ from separator & Ethylbenzene & 1,200 & C & $n / a$ \\
\hline WY-4586 & Fremont & $5 \mathrm{~m}$ from separator & Mixed xylenes & 4,100 & C, I & $\mathrm{n} / \mathrm{a}$ \\
\hline WY-4586 & Fremont & $5 \mathrm{~m}$ from separator & n-hexane & 22,000 & C & $\mathrm{n} / \mathrm{a}$ \\
\hline WY-1103 & Fremont & $20 \mathrm{~m}$ from separator & benzene & 31 & $C, I, A$ & $1 / 100,000$ \\
\hline$W Y-2069$ & Fremont & 110 m from work-over rig ${ }^{a}$ & Hydrogen sulfide & 30 & । & $\mathrm{n} / \mathrm{a}$ \\
\hline WY-4861 & Fremont & $5 \mathrm{~m}$ from separator & Benzene & 230 & $C, I, A$ & $1 / 10,000$ \\
\hline$W Y-4861$ & Fremont & $5 \mathrm{~m}$ from separator & Mixed xylenes & 317 & C & $\mathrm{n} / \mathrm{a}$ \\
\hline$W Y-4861$ & Fremont & $5 \mathrm{~m}$ from separator & n-hexane & 2,500 & C & $\mathrm{n} / \mathrm{a}$ \\
\hline WY-4478 & Park & $25 \mathrm{~m}$ from separator & Hydrogen sulfide & 91 & । & $\mathrm{n} / \mathrm{a}$ \\
\hline$W Y-4478$ & Park & $25 \mathrm{~m}$ from separator & Benzene & 110,000 & $C, I, A$ & $1 / 10,000$ \\
\hline WY-4478 & Park & $25 \mathrm{~m}$ from separator & Toluene & 270,000 & C, A & $\mathrm{n} / \mathrm{a}$ \\
\hline WY-4478 & Park & $25 \mathrm{~m}$ from separator & Mixed xylenes & 135,000 & $C, I, A$ & $\mathrm{n} / \mathrm{a}$ \\
\hline WY-4478 & Park & $25 \mathrm{~m}$ from separator & n-hexane & $1,200,000$ & C & $\mathrm{n} / \mathrm{a}$ \\
\hline WY-129 & Park & $55 \mathrm{~m}$ from separator & benzene & 100 & $C, I, A$ & $1 / 10,000$ \\
\hline WY-3321 & Park & $5 \mathrm{~m}$ from compressor & benzene & 35 & $C, I, A$ & $1 / 100,000$ \\
\hline WY-4883-005 & Park & $5 \mathrm{~m}$ from compressor & Formaldehyde & 46 & C, I & $1 / 10,000$ \\
\hline$W Y-4864$ & Park & $5 \mathrm{~m}$ from discharge canal & Hydrogen sulfide & 210 & $\mathrm{I}, \mathrm{A}$ & $\mathrm{n} / \mathrm{a}$ \\
\hline WY-4865 & Park & 10 m from discharge canal & Hydrogen sulfide & 1,200 & $\mathrm{I}, \mathrm{A}$ & $\mathrm{n} / \mathrm{a}$ \\
\hline WY-4496 & Park & $20 \mathrm{~m}$ from well pad & Hydrogen sulfide & 6,100 & $\mathrm{I}, \mathrm{A}$ & $n / a$ \\
\hline WY-106 & Park & Adjacent to discharge canal & Hydrogen sulfide & 5,600 & $\mathrm{I}, \mathrm{A}$ & $n / a$ \\
\hline WY-184 & Park & 15 m from discharge canal & Hydrogen sulfide & 240 & $\mathrm{I}, \mathrm{A}$ & $\mathrm{n} / \mathrm{a}$ \\
\hline WY-187 & Park & 15 m from discharge canal & Hydrogen sulfide & 66,000 & $\mathrm{I}, \mathrm{A}$ & $\mathrm{n} / \mathrm{a}$ \\
\hline WY-187 & Park & 15 m from discharge canal & Benzene & 23 & $C, 1$ & $1 / 100,000$ \\
\hline
\end{tabular}

$\mathrm{C}=$ chronic $; \mathrm{A}=$ acute $\mathrm{I}=$ intermediate.

anfrastructure used to pull and replace a well completion. 
Table 4 Concentrations of volatile compounds exceeding health-based risk levels in samples collected in Arkansas

\begin{tabular}{|c|c|c|c|c|c|c|}
\hline State/ID & County & Nearest infrastructure & Chemical & $\begin{array}{c}\text { Concentration } \\
\left(\mu \mathrm{g} / \mathrm{m}^{3}\right)\end{array}$ & $\begin{array}{c}\text { ATSDR MRLs } \\
\text { exceeded }\end{array}$ & $\begin{array}{l}\text { EPA IRIS cancer } \\
\text { risk exceeded }\end{array}$ \\
\hline AR-3136-003 & Faulkner & $355 \mathrm{~m}$ from compressor & Formaldehyde & 36 & $C$ & $1 / 10,000$ \\
\hline AR-3136-001 & Cleburne & $42 \mathrm{~m}$ from compressor & Formaldehyde & 34 & C & $1 / 10,000$ \\
\hline AR-3561 & Cleburne & $30 \mathrm{~m}$ from compressor & Formaldehyde & 27 & C & $1 / 10,000$ \\
\hline AR-3562 & Faulkner & $355 \mathrm{~m}$ from compressor & Formaldehyde & 28 & C & $1 / 10,000$ \\
\hline AR-4331 & Faulkner & $42 \mathrm{~m}$ from compressor & Formaldehyde & 23 & C & $1 / 10,000$ \\
\hline AR-4333 & Faulkner & $237 \mathrm{~m}$ from compressor & Formaldehyde & 44 & $C, I$ & $1 / 10,000$ \\
\hline AR-4724 & Van Buren & $42 \mathrm{~m}$ from compressor & 1,3-butadiene & 8.5 & $\mathrm{n} / \mathrm{a}$ & $1 / 10,000$ \\
\hline AR-4924 & Faulkner & $254 \mathrm{~m}$ from compressor & Formaldehyde & 48 & $C, 1$ & $1 / 10,000$ \\
\hline
\end{tabular}

$\mathrm{C}=$ chronic; $\mathrm{I}=$ intermediate.

volatiles at concentrations that exceeded ATSDR MRLs or EPA IRIS cancer risk levels (Table 3, Figure 2).

\section{Arkansas (Cleburne, Faulkner, and Van Buren Counties)}

One of the 8 grab samples, and 7 of the 13 passive samples, contained volatiles above ATSDR MRLs or EPA IRIS risk levels. One of the passive samples (taken at a residence) had formaldehyde levels that were close to the ATSDR MRL and exceeded EPA's 1/10,000 cancer risk level (Table 4, Figure 3).

\section{Pennsylvania (Susquehanna County)}

One of the four grab samples contained benzene at concentrations that exceeded the EPA 1/100,000 cancer risk level. Six of the ten passive samples contained formaldehyde at levels that exceeded ATSDR MRLs or EPA IRIS risk levels. Two of the samples exceeded both the acute MRL and the 1/10,000 cancer risk level (Table 5, Figure 4).

\section{Colorado (Boulder and Weld Counties)}

One of the five grab samples contained 41 micrograms per cubic meter of hydrogen sulfide and exceeded the
ATSDR intermediate MRL. None of the passive samples had volatiles exceeding the ATSDR MRLs or EPA IRIS risk levels.

Ohio (Athens, Carroll, and Trumbull Counties)

None of the four grab samples or five passive samples contained volatiles at concentrations that exceeded the ATSDR MRLs or EPA IRIS risk levels.

\section{State air quality monitoring survey}

We reviewed air quality monitoring by state agencies in the five states covered by our sampling. We reviewed one study in Arkansas, seven in Colorado, one in Ohio, four in Pennsylvania, and one in Wyoming. Most of the studies measured VOC levels, two included hydrogen sulfide, and seven included methane and/or other hydrocarbons. Sampling durations ranged from four hours to 24 months; five of the studies lasted more than four weeks. Target compounds were detected in all studies that have been completed, including mixtures of 42 nonmethane VOCs. None of the studies concluded that detected compounds posed significant human health risk (Table 6).

Table 5 Concentrations of volatile compounds exceeding health-based risk levels in samples collected in Pennsylvania

\begin{tabular}{|c|c|c|c|c|c|c|}
\hline State/ID & County & Nearest infrastructure & Chemical & $\begin{array}{c}\text { Concentration } \\
\left(\mu \mathrm{g} / \mathrm{m}^{3}\right)\end{array}$ & $\begin{array}{c}\text { ATSDR MRLs } \\
\text { exceeded }\end{array}$ & $\begin{array}{l}\text { EPA IRIS cancer } \\
\text { risk exceeded }\end{array}$ \\
\hline PA-4083-003 & Susquehanna & $420 \mathrm{~m}$ from compressor & Formaldehyde & 8.3 & & $1 / 10,000$ \\
\hline PA-4083-004 & Susquehanna & $370 \mathrm{~m}$ from compressor & Formaldehyde & 7.6 & & $1 / 100,000$ \\
\hline PA-4136 & Washington & 270 m from PIG launch ${ }^{a}$ & Benzene & 5.7 & & $1 / 100,000$ \\
\hline PA-4259-002 & Susquehanna & $790 \mathrm{~m}$ from compressor & Formaldehyde & 61 & $C, I, A$ & $1 / 10,000$ \\
\hline PA-4259-003 & Susquehanna & $420 \mathrm{~m}$ from compressor & Formaldehyde & 59 & $C, I, A$ & $1 / 10,000$ \\
\hline PA-4259-004 & Susquehanna & $230 \mathrm{~m}$ from compressor & Formaldehyde & 32 & C & $1 / 10,000$ \\
\hline PA-4259-005 & Susquehanna & $460 \mathrm{~m}$ from compressor & Formaldehyde & 34 & C & $1 / 10,000$ \\
\hline
\end{tabular}

C = chronic; A = acute; I = intermediate.

ataunching station for pipeline cleaning or inspection tool. 


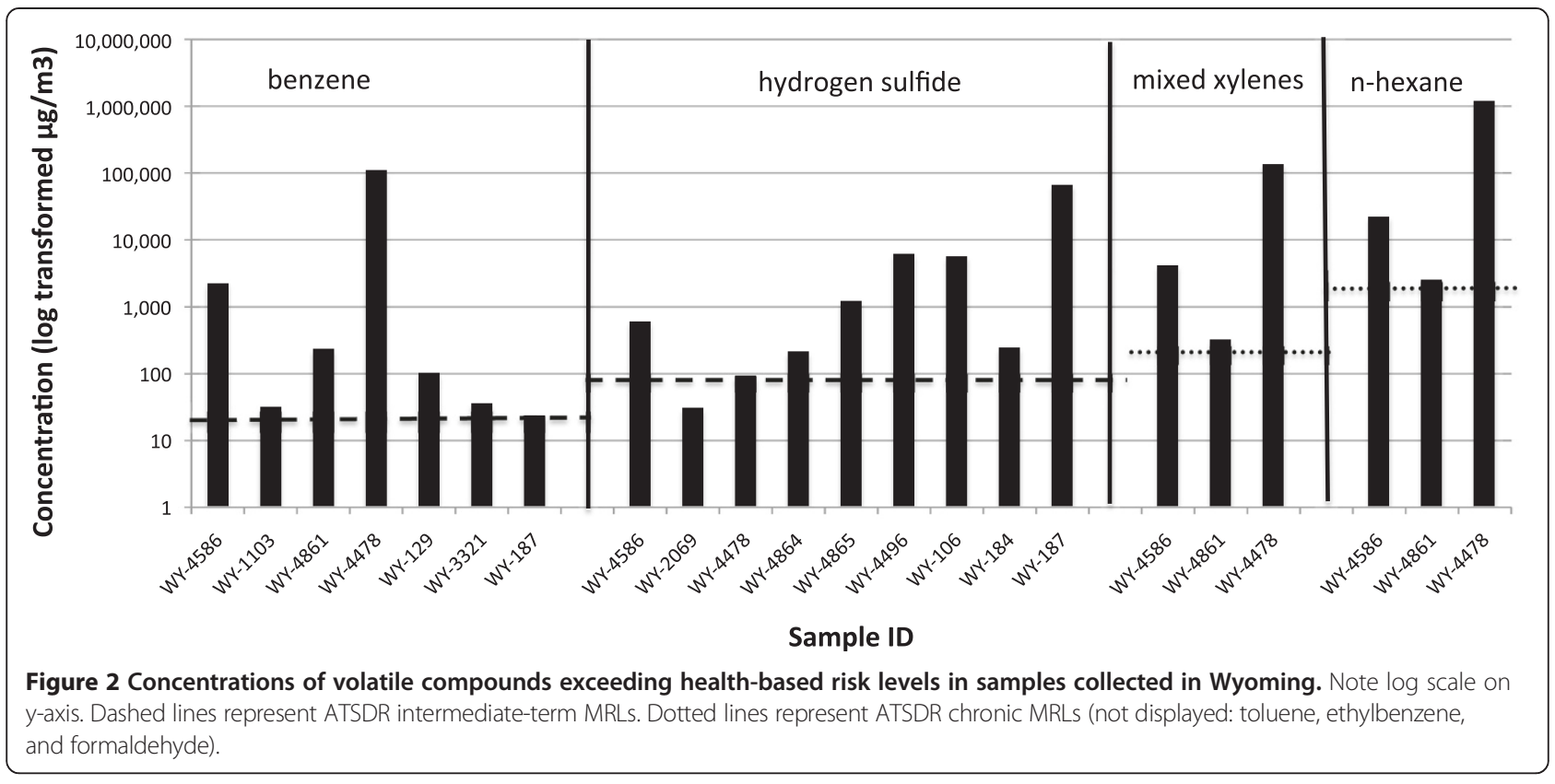

\section{Discussion}

We identified significant concentrations of four wellcharacterized chemicals: benzene, formaldehyde, hexane, and hydrogen sulfide. Benzene was detected at sample locations in Pennsylvania and Wyoming. Concentrations exceeded health-based risk levels by as many as several orders of magnitude. Previous studies similarly found benzene concentrations near oil and gas development $[10,11]$. Our monitors detected benzene at higher concentrations $\left(5.7-110,000 \mu \mathrm{g} / \mathrm{m}^{3}\right)$ than those found in the published literature. The results are of concern given their proximity to subdivisions, homes, and farms. In Wyoming, multiple samples with high benzene concentrations were taken on residential property 30-350 yards from the nearest well, or on farmland along the perimeter of a well pad. Equipment included separators, compressor stations, discharge canals, and pipeline cleaning operations. The results suggest that existing regulatory setback distances from wells to

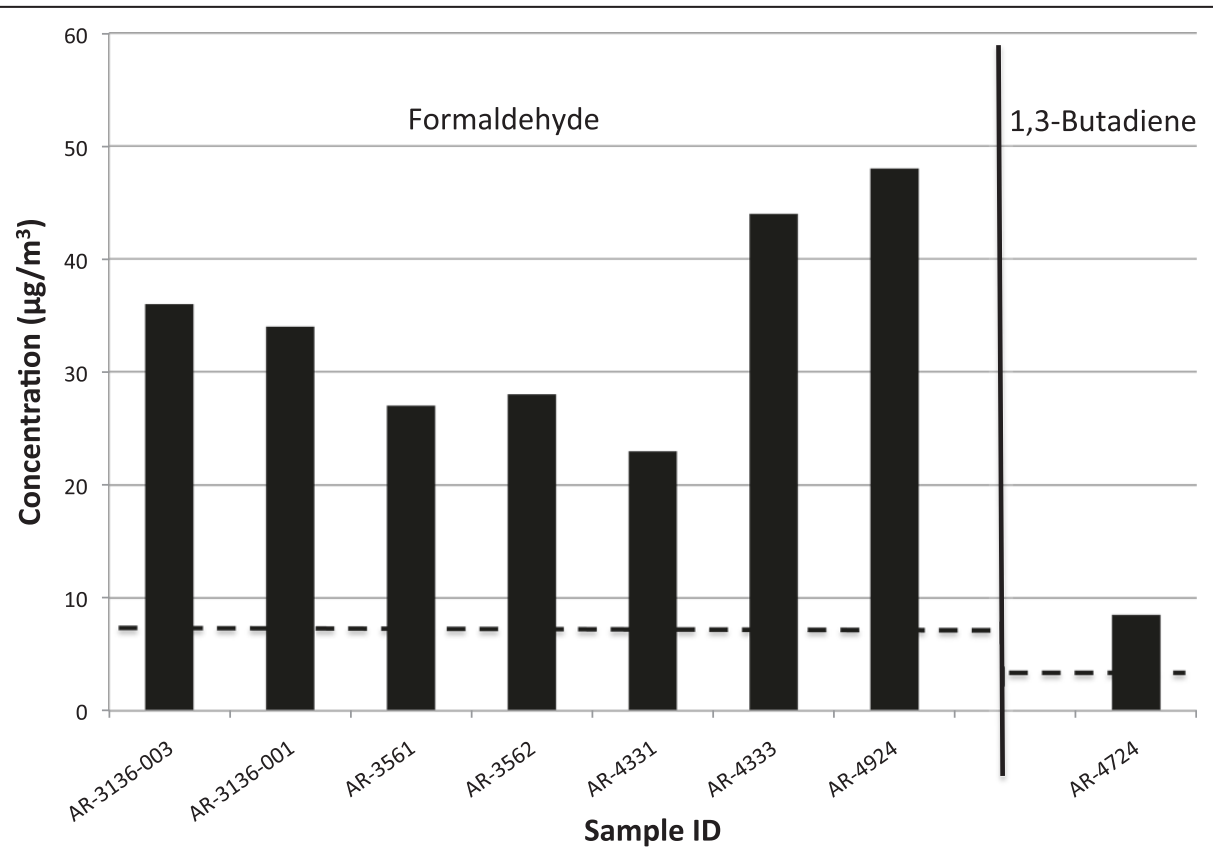

Figure 3 Concentrations of volatile compounds exceeding health-based risk levels in samples collected in Arkansas. Dashed lines represent EPA IRIS 1/10,000 cancer risk for formaldehyde and 1,3 butadiene. 


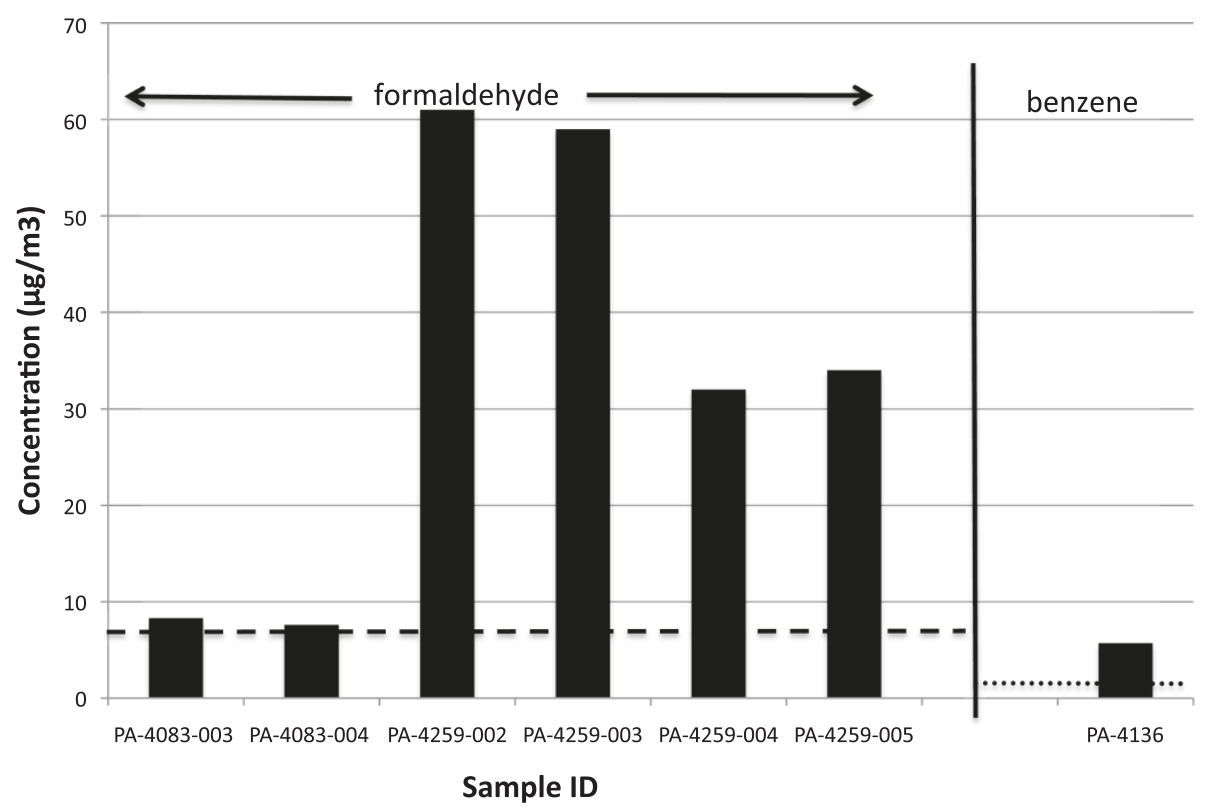

Figure 4 Concentrations of volatile compounds exceeding health-based risk levels in samples collected in Pennsylvania. Dashed line represents EPA IRIS 1/10,000 cancer risk for formaldehyde. Dotted line represents EPA IRIS 1/100,000 cancer risk for benzene.

residences may not be adequate to reduce human health risks [61]. Setbacks from wellheads to homes and other occupied structures cluster around the 150 to 500 feet range in the five states (see Table 1). We found high concentrations of volatile compounds at greater distances, including formaldehyde (up to 2,591 feet) and benzene (up to 885 feet). High levels of benzene near oil production wells indicate that EPA should revisit the extent to which oil wells are addressed in its new source performance standards [62].

Benzene is a known human carcinogen. Chronic exposure to benzene increases the risk of leukemia [63]. The increased risk occurs at low levels of exposure with no evidence of threshold level [64]. Benzene exposure increases risk of birth defects [65], including neural tube and other defects found near natural gas development [24]. Respiratory effects include pulmonary edema, acute granular tracheitis, laryngitis, and bronchitis [60].

UOG fields present multiple sources and exposure routes for benzene. Benzene occurs naturally in shale and other hydrocarbon deposits, and is vented, flared, or released as fugitive emissions along numerous points of production, such as wells, production tanks, compressors, and pipelines [6]. It can volatize and disperse from flowback and produced water at drilling sites and remain in the air for several days [66]. It was among the first pollutants found in air samples near shale gas operations [67]. Previous studies found benzene to be the largest contributor to excess lifetime cancer risk near gas fields [12]. Residents exposed to VOCs including benzene experience immediate health symptoms and illness. Within days after a flaring event at a
Texas City refinery, children exhibited altered blood profiles, liver enzymes, and somatic symptoms [68]. Future research is needed to determine whether the concentrations of benzene we measured are due to continuous releases or flaring, fugitive emissions, or facility upsets.

Formaldehyde is another volatile compound that exceeded health-based risk levels near compressor stations in Arkansas, Pennsylvania, and Wyoming. As with benzene, there are known sources of formaldehyde emissions along the production chain. Formaldehyde is a product of incomplete combustion emitted by natural gas-fired reciprocating engines at compressor stations [69]. Formaldehyde is also formed from methane in the presence of sunlight, which may be an important source given significant amounts of methane that are known to escape from UOG sites [70]. But air monitoring studies, particularly in shale gas regions, either do not measure for formaldehyde $[12,14]$ or find it at lower concentrations. For example, the Barnett Shale Energy Education Council [71] found levels that did not pose a risk to human health. Colborn et al. [10] found formaldehyde and acetaldehyde in each of 46 samples with a mean of 1.0 part per billion by volume. In contrast, our CBPR framework resulted in the targeting of compressor stations for passive sampling, where diesel emissions likely account for the higher levels that we found. Our results are similar to the Fort Worth Natural Gas Air Quality Study, which found formaldehyde concentrations in areas with multiple large compressor engines [72]. We found high concentrations of formaldehyde near fourteen compressor stations in three states. 
Table 6 Five-state survey of air quality monitoring studies, unconventional oil and gas operations

\begin{tabular}{|c|c|c|c|c|c|}
\hline Agency (year) & Target compound & Sampling equipment & Sample sites & Duration & Representative findings \\
\hline ADEQ (2011) & $\begin{array}{l}\text { VOCs (total) } \\
\mathrm{NO} \\
\mathrm{NO}_{2}\end{array}$ & $\begin{array}{c}\text { PID (fixed) } \\
\text { PID (handheld) }\end{array}$ & $\begin{array}{l}4 \text { compressor stations } \\
6 \text { drilling sites } \\
3 \text { well sites (fracking) } \\
1 \text { upwind }\end{array}$ & $\begin{array}{c}1 \mathrm{~d} \\
(4-6 \mathrm{hrs} .)\end{array}$ & $\begin{array}{c}\text { VOCs "almost always below or near detection limits" } \\
\text { VOCs at drilling sites elevated (ave. 38-678 ppb; max. 350-5,321 ppb) } \\
\mathrm{NO} / \mathrm{NO}_{2} \text { rarely exceed detection limits }\end{array}$ \\
\hline CDPHE (2012) & $\begin{array}{l}\text { NMOCs (78) } \\
\text { Methane }\end{array}$ & Canister & 1 well pad (Erie) & 3 wks. & $\begin{array}{c}\text { Detects }=42 \text { of } 78 \text { compounds in }>75 \% \text { of samples } \\
\text { Benzene "well within EPA's acceptable cancer risk range" } \\
\text { Acute and chronic HQs "well below" } 1\end{array}$ \\
\hline CDPHE (2009) & $\begin{array}{l}\text { NMOCs (78) } \\
\text { VOCs } \\
\text { PM }_{2.5}\end{array}$ & $\begin{array}{l}\text { Canister } \\
\text { PID (handheld) } \\
\text { Filter (handheld) }\end{array}$ & $\begin{array}{l}8 \text { wells ( } 4 \text { drilling, } \\
4 \text { completion) }\end{array}$ & $1 d$ & $\begin{array}{l}\text { Total NMOC ave. } 273-8,761 \mathrm{ppb} \text { at } 8 \text { sites } \\
\text { Total VOC ave. } 6-3,023 \mathrm{ppb} \text { at } 8 \text { sites } \\
\text { PM }_{2.5} \text { ave. } 7.3-16.7 \mu \mathrm{g} / \mathrm{m}^{3} \text { at } 8 \text { sites }\end{array}$ \\
\hline $\begin{array}{c}\text { CDPHE, } \\
\text { GCPHD (2007) }\end{array}$ & $\begin{array}{l}\text { VOCs (43) } \\
\mathrm{PM}_{10}\end{array}$ & $\begin{array}{l}\text { Canister } \\
\text { Filter }\end{array}$ & $\begin{array}{l}14 \text { sites } \\
7 \text { sites }\end{array}$ & 24 mos. & $\begin{array}{l}\text { Detects }=15 \text { of } 43 \text { compounds } \\
\text { Benzene ave. } 28.2 \mu \mathrm{g} / \mathrm{m}^{3}, \max 180 \mu \mathrm{g} / \mathrm{m}^{3} \text { (grab) } \\
\text { Toluene ave. } 91.4 \mu \mathrm{g} / \mathrm{m}^{3}, \max 540 \mu \mathrm{g} / \mathrm{m}^{3} \text { (grab) }\end{array}$ \\
\hline $\begin{array}{c}\text { CDPHE } \\
(2003-2012)\end{array}$ & $\begin{array}{l}\text { NMOCs } \\
\text { Carbonyls }\end{array}$ & Canister & $\begin{array}{l}5 \text { sites }(2003) \\
6 \text { sites }(2006) \\
3+\text { sites }(2012)\end{array}$ & 2 mos. & $\begin{array}{c}\text { Methane ave. 2,535 ppb (Platteville) vs. (1,780 ppb Denver) } \\
\text { Top NMOCs in Platteville = ethane, propane, butane } \\
\text { Benzene, toluene higher in Platteville }\end{array}$ \\
\hline CDPHE (2002) & $\begin{array}{l}\mathrm{VOCs}(42) \\
\mathrm{SO}_{2} \\
\mathrm{NO}, \mathrm{NO}_{2}\end{array}$ & $\begin{array}{l}\text { Canister } \\
\text { Continuous }\end{array}$ & $\begin{array}{l}2 \text { well sites } \\
1 \text { residential } \\
1 \text { active flare } \\
2 \text { up-, down-valley } \\
1 \text { background }\end{array}$ & $1 \mathrm{mo}$ & $\begin{array}{l}\text { Detects }=6 \text { of } 42 \mathrm{VOCs} \\
\text { Benzene in } 6 \text { of } 20\left(2.2-6.5 \mu \mathrm{\mu g} / \mathrm{m}^{3}\right) \\
\text { Toluene in } 18 \text { of } 20\left(1.5-17 \mu \mathrm{gg} / \mathrm{m}^{3}\right)\end{array}$ \\
\hline OEPA (2014) & $\begin{array}{l}\text { VOCs (69) } \\
\text { VOCs } \\
\mathrm{PM}_{10} / \mathrm{PM}_{2.5} \\
\mathrm{H}_{2} \mathrm{~S} \\
\mathrm{CO}\end{array}$ & $\begin{array}{l}\text { Canister } \\
\text { GC/MS } \\
\text { Filter }\end{array}$ & $\begin{array}{l}1 \text { well site } \\
1 \text { remote site }\end{array}$ & 12 mos. & $\begin{array}{l}\text { Ongoing; data update provided in February } 2014 \\
\text { Detects include BTEX, alkanes (e.g., ethane, hexane), } \mathrm{H}_{2} \mathrm{~S} \\
\text { Second site planned near processing plant }\end{array}$ \\
\hline PA DEP (2010) & $\begin{array}{l}\text { VOCs (48) } \\
\text { Alkanes } \\
\text { Leak detection }\end{array}$ & $\begin{array}{l}\text { Canister } \\
\text { OP-FTIR } \\
\text { GC/MS } \\
\text { FLIR }\end{array}$ & $\begin{array}{l}2 \text { compressor stations } \\
1 \text { condensate tank } \\
1 \text { wastewater impoundment } \\
1 \text { background }\end{array}$ & 5 wks. & $\begin{array}{c}\text { Detects include methane, ethane, propane, benzene (max. } 758 \text { ppb) } \\
\text { No conc.'s "that would likely trigger air-related health issues" } \\
\text { Fugitive gas stream emissions }\end{array}$ \\
\hline PA DEP (2011) & $\begin{array}{l}\text { VOCs (48) } \\
\text { Alkanes } \\
\text { Leak detection }\end{array}$ & $\begin{array}{l}\text { Canister } \\
\text { OP-FTIR } \\
\text { GC/MS } \\
\text { FLIR }\end{array}$ & $\begin{array}{l}2 \text { compressor stations } \\
1 \text { completed well } \\
1 \text { well site (fracking) } \\
1 \text { well (tanks, separator) } \\
1 \text { background }\end{array}$ & 4 wks. & $\begin{array}{l}\text { Detects include BTEX (benzene max. } 400 \text { ppb), methylbenzenes } \\
\text { No conc.'s "that would likely trigger air-related health issues" } \\
\text { Fugitive emissions from condensate tanks, piping }\end{array}$ \\
\hline PA DEP (2011) & $\begin{array}{l}\text { VOCs (48) } \\
\text { Alkanes }\end{array}$ & $\begin{array}{l}\text { Canister } \\
\text { OP-FTIR } \\
\text { GC/MS }\end{array}$ & $\begin{array}{l}2 \text { compressor stations } \\
1 \text { well site (flaring) } \\
1 \text { well site (drilling) } \\
1 \text { background }\end{array}$ & 4 wks. & $\begin{array}{l}\text { Detects include benzene (max. } 400 \text { ppb), toluene, ethylbenzene } \\
\text { Natural gas constituent detects near compressor stations } \\
\text { Conc.'s "do not indicate a potential for major air-related health issues" }\end{array}$ \\
\hline PA DEP (2012) & $\begin{array}{l}\text { Criteria } \\
\text { VOCs/HAPs } \\
\text { Methane } \\
\quad \mathrm{H}_{2} \mathrm{~S}\end{array}$ & "Full suite" & $\begin{array}{c}1 \text { gas processing } \\
2 \text { large compressor stations } \\
1 \text { background }\end{array}$ & 12 mos. & Ongoing; report due in 2014 \\
\hline
\end{tabular}


Table 6 Five-state survey of air quality monitoring studies, unconventional oil and gas operations (Continued)

\begin{tabular}{|c|c|c|c|c|c|}
\hline WDEQ (2013) & $\begin{array}{l}\text { VOCs/NMHCs } \\
\text { Ozone } \\
\text { Methane } \\
\mathrm{NO}, \mathrm{NO}_{2} \\
\mathrm{PM}_{10} / \mathrm{PM}_{25}\end{array}$ & $\begin{array}{l}\text { Canister } \\
\text { UV Photometric } \\
\text { FID } \\
\text { Chemiluminescence } \\
\text { Beta Attenuation }\end{array}$ & $\begin{array}{c}7 \text { permanent stations (e.g., Boulder, Juel Spring, Moxa) } \\
3 \text { mesonet stations (Mesa, Paradise Warbonnet) } \\
2 \text { mobile trailer locations (Big Piney, Jonah Field) }\end{array}$ & Ongoing & $\begin{array}{l}\text { WDEQ mobile monitors placed at locations w/ oil \& gas development } \\
\text { Mini-SODAR also placed adjacent to Boulder permanent station } \\
\text { "Relatively low concentrations" of VOCs found in canister samples } \\
\text { VOCs "consistently higher" at Paradise site (near oil \& gas sources) }\end{array}$ \\
\hline
\end{tabular}

BTEX = benzene, toluene, ethylbenzene, and xylenes; FID = flame ionization detector; FLIR = forward looking infrared; GC/MS = gas chromatography/mass spectrometry; HAP = hazardous air pollutant; NAAQS = National Ambient Air Quality Standard; NMHC = non-methane hydrocarbon; NMOC = non-methane organic compound; OP-FTIR = open-path Fourier transform infrared; PID = photoionization detector; VOC = volatile organic compound. 
Formaldehyde is a suspected human carcinogen [73]. It can affect nearly every tissue in the human body, leading to acute (dermal allergies, asthma) and chronic (neuro-, reproductive, hematopoietic, genetic and pulmonary toxicity and cellular damage) health effects [74]. The science of childhood exposure to formaldehyde is progressing rapidly [75]. State agencies and international organizations continue to lower exposure limit values and guidelines for formaldehyde [76]. Our results exceed those guidelines. Symptoms reported by community members mirror the effects of acute formaldehyde exposure, which causes irritation of the eyes, nose, throat, and skin.

Other volatiles of concern included hexane and hydrogen sulfide. Hexane detects were most prevalent near oil and gas operations in Wyoming near well pads, compressor stations, separators, and produced water discharges. Other studies in oil and gas regions found hexane, but at low concentrations $[10,12]$. The circumstances under which high concentrations of hexane were found in Wyoming suggest a combination of leaks, spills, and fugitive emissions as potential causes. Acute exposure to hexane affects the central nervous system, causing dizziness, nausea, and headache. Chronic effects include neurotoxicity [77].

We also found elevated levels of hydrogen sulfide in Wyoming along the chain of production (pump jacks, produced water discharge impoundments, discharge canals) and near a well pad in Colorado. Hydrogen sulfide is a broad-spectrum toxicant that can impact most organ systems [78]. As such, it contributes to a range of shortand long-term neurological, upper respiratory, and bloodrelated symptoms, including those that were prevalent among community samplers in Wyoming (headaches, dizziness, eye irritation, fatigue) [79]. Hydrogen sulfide is a natural component of crude oil and natural gas [5] and is released during many industrial processes. In addition, five samples from Wyoming exceeded ATSDR health-based risk levels for toluene and xylenes.

Health-based risk levels provide only a limited sense of potential human health impacts from air emissions. They do not fully account for vulnerable subpopulations, and toxicity values are available for a comparatively small number of compounds. The levels that we found for the above chemicals of concern suggest that state monitoring studies are incomplete. Recent state-funded projects found air volatiles at UOG sites that were either near detection limits or within acceptable limits to protect the public [80-82]. One area of agreement between our community-based and state monitoring studies concerns the presence of complex chemical mixtures. These mixtures demonstrate the contingent nature of ambient air quality near UOG infrastructure.

For example, one sample, taken midday in early winter near a well pad in Wyoming with clicking pneumatic pumps, found high concentrations of hydrogen sulfide, hexane, benzene, and xylenes. It also captured cyclohexane, heptane, octane, ethylbenzene, nonane, 1,2,4-trimethylbenzene, and 15 tentatively identified compounds (TICs). TICs are compounds that a device or analytic process is not designed to measure. Total VOC concentrations in the sample exceeded 1.6 million $\mu \mathrm{g} / \mathrm{m}^{3}$, excluding methane. While toxicity values are not available for every TIC in our samples, they exceeded reference concentrations available for related compounds such as hexane [77]. Another sample taken in Arkansas, during autumn in the afternoon near a compressor station, captured 17 volatile compounds and five TICs. A third sample, near a separator shed in Wyoming in late autumn at midday, showed spikes in hydrogen sulfide, benzene, and hexane, 19 additional VOCs, and 15 TICs, with total VOC concentrations exceeding 25 million $\mu \mathrm{g} / \mathrm{m}^{3}$, excluding methane. These and other complex mixtures are provided in Additional file 1.

The mixtures that we identified are related to sources commonly used in well pad preparation, drilling, well completion, and production, such as produced water tanks, glycol dehydrators, phase separators, compressors, pipelines, and diesel trucks [14]. They can be released during normal operating conditions and persist near ground level, especially in regions where topography encourages air inversions [83]. The toxicity of some constituents is well known, while others have little or no toxicity information available. Our findings of chemical mixtures are of clinical significance, even absent spikes in chemicals of concern. The chemical mixtures that we identified should be further investigated for their primary emissions sources as well as their potential cumulative and synergistic effects [84]. Clinical and subclinical effects of hydrocarbons such as benzene are increasingly found at low doses [85]. Chronic and subchronic exposure to chemical mixtures is of particular concern to vulnerable subpopulations, including children, pregnant women, and senior citizens [86].

Apart from chemicals of concern (including known and suspected human carcinogens) and chronic exposure to complex mixtures, our findings point to the value of community-based research to inform state testing protocols. Air quality near the diverse range of equipment and stages of UOG development is inherently complex. While states sometimes rely on state-of-the-art technologies such as wireless sensors to characterize local air quality, they continue to collect only a "snapshot" of near-field conditions. For example, Arkansas carried out a technologically ambitious program, placing multi-sensor gas monitors on five-foot tripods along each perimeter of a well pad at several sites. AreaRAEs (the trade name for a wireless monitor produced by RAE Systems) use electrochemical sensors to measure nitrous oxides and a photoionization detector to determine VOC concentration. 
The continuous monitors wirelessly transmitted data at five-second intervals over a four- to six-hour period (see Table 6). In addition, Arkansas Department of Environmental Quality (ADEQ) personnel carried handheld versions of the AreaRAE along the perimeter of the sites every one or two hours. While the study did not identify individual VOCs, it found that total VOC emissions at the edge of a well pad fluctuate wildly over a five-hour period. The agency concluded, "The spatial and temporal distribution of VOC concentrations at most drilling sites was significantly affected by monitor location, wind, and the interaction between location and wind direction" [81]. Other studies noted similar variation, although the extent to which short-term spikes and unique chemical mixtures might pose a risk to human health was not considered.

Community-based research can improve the spatial and temporal resolution of air quality data [87] while adhering to established methods. Our findings can inform and calibrate state monitoring and research programs. Additional file 1: Table S6 gives a more in-depth overview of community monitoring in action, including sample site selection factors, sources of public health concern at each site, and the range of infrastructure present and life cycle stage when samples were taken. For example, grab samples in Wyoming with some of the highest VOC concentrations were collected during production, as opposed to well completion (see Table S6, Additional file 1). The timing and location of our samples were driven by two primary factors: local knowledge gleaned from daily routines, and a history of chronic or subchronic symptoms reported by nearby residents. For example, a separator shed was targeted because of subchronic symptoms (dizziness, nausea, tight chest, nose and throat problems, metallic taste, and sweet smell) and loud sounds nearby ("hissing, clicking, and whooshing"). Well pads were selected based on impacts to livestock, pasture degradation from produced water, and observations of residents and farmers. Other samples were driven by observations of fugitive emissions, including vapor clouds, deposition, discoloration, and sounds (see Table S6 in Additional file 1).

Community-based research can identify mixtures, and their potential emissions sources, to prioritize for study of their additive, cumulative, and synergistic effects [88]. The mixtures can be used to determine source signatures [14] and isolate well pads for more intensive monitoring. Symptom-driven samples can define the proper length of a sampling period, which is often limited to days or weeks. They can inform equipment placement for continuous monitoring and facilitate a transition from exploratory to more purposive sampling. Testing informed by human health impacts, and more precise knowledge of the mix and spacing of sources that may contribute to them, contrasts with state efforts, which are limited by access to property, sources of electrical power, fixed monitoring sites, and the cooperation of well pad owners and operators. In these ways, communitybased monitoring can extend the reach of limited public resources.

\section{Conclusions}

Community-based monitoring near unconventional oil and gas operations demonstrates elevations in concentrations of hazardous air pollutants under a range of circumstances. Of special concern are high concentrations of benzene, hydrogen sulfide, and formaldehyde, as well as chemical mixtures linked to operations with observed impacts to resident quality of life.

\section{Additional file}

Additional file 1: Contains six tables, including complete results from grab and passive sampling (Tables S1 through S5) and data on sample location selection in Wyoming (Table S6).

\section{Abbreviations}

ADEQ: Arkansas Department of Environmental Quality; ATSDR: Agency for Toxic Substances and Disease Registry; BTEX: benzene, toluene, ethylbenzene, and xylenes; CBPR: community-based participatory research; CDPHE: Colorado Department of Public Health and Environment; EMPACT: Environmental Monitoring for Public Access and Community Tracking; EPA: Environmental Protection Agency; FID: flame ionization detector; FLIR: forward looking infrared; GCM: Global Community Monitor; GC/MS: gas chromatography/mass spectrometry; GCPHD: Garfield County Public Health Department; HAP: hazardous air pollutant; IRIS: Integrated Risk Information System; MRL: minimal risk level; NAAQS: National Ambient Air Quality Standard; NIOSH: National Institute for Occupational Safety and Health; NMHC: non-methane hydrocarbon; NMOC: non-methane organic compound; OEPA: Ohio Environmental Protection Agency; OP-FTIR: open path Fourier transform infrared; PA DEP: Pennsylvania Department of Environmental Protection; PAH: polycyclic aromatic hydrocarbon; PID: photoionization detector; QA/QC: Quality Assurance/Quality Control; TIC: tentatively identified compound; UOG: unconventional oil and gas; VOC: volatile organic compound; WDEQ: Wyoming Department of Environmental Quality.

\section{Competing interests}

The authors declare they have no competing financial interest. Ruth Breech, Mark Chernaik, Caroline Cox, Denny Larson, and Deb Thomas are employed by non-profit organizations whose mission is to reduce exposure to toxic chemicals.

\section{Authors' contributions}

GPM provided study design and project management, a survey of statesponsored air quality monitoring studies, data analysis, and initial drafts of the Background, Methods, Discussion, and Tables 1 and 6, and Additional file 1: Tables S1 through S6. RB managed air quality monitoring teams and provided an initial draft of the Methods. MC provided data analysis and interpretation of grab and passive samples. CC provided data analysis and interpretation of grab and passive samples and initial drafts of the Results, Tables 2, 3, 4, 5 and Figures 2, 3 and 4. DL developed the protocol for community-based air sampling and provided an initial draft of the Methods. DT managed air quality monitoring teams in Wyoming and provided an initial draft of Additional file 1: Table S6. DOC provided study design and guidance, data analysis, and initial drafts of the Background and Discussion. All authors participated in the study design, data analysis and interpretation, and drafting of the manuscript. All authors read and approved the final manuscript. 


\section{Acknowledgements}

Support provided by the V. Kann Rasmussen Foundation, the Center for Health, Science, and Public Policy, and the Institute for Health and the Environment. We thank Tom Bengera, Rod Brueske, Dirk DeTurck, Paul Feezel, Catherine Fenton, John Fenton, Frank Finan, Jessica Hendricks, Christine Hughes, Caitlin Kennedy, April Lane, Emily Lane, Evelyn Meisenbacher, Doug McMullin, Genie McMullin, Ansje Miller, Teresa Mills, Angie Nordstrum, Jen Palazzolo, Sharyle Patton, Sharon Proudfoot, Molly Rauch, Rebecca Roter, Andrea Roy, Deborah Sonderman, Steve Taylor, Ellen Webb, and John Williams, and the following organizations for their contributions to this article: Appalachia Resist, ArkansasFracking.org, Athens County Fracking Action Network, Breathe Easy Susquehanna County, Buckeye Forest Council, Carroll County Concerned Citizens, Center for Environmental Health, Center for Health, Environment \& Justice, Coming Clean Inc., Commonweal, Erie Rising, Frack Free Mahoning Valley, Global Community Monitor, Moms Clean Air Force, and Powder River Basin Resource Council. We sincerely thank three reviewers for their detailed comments and suggestions.

\section{Author details}

'Center for Health, Science, and Public Policy, Brooklyn Law School, Brooklyn, New York, USA. ${ }^{2}$ Global Community Monitor, Richmond, California, USA. ${ }^{3}$ Environmental Law Alliance Worldwide, Eugene, Oregon, USA. ${ }^{4}$ Center for Environmental Health, Oakland, California, USA. ${ }^{5}$ Powder River Basin Resource Council, Clark, Wyoming, USA. 'Institute for Health and the Environment, University at Albany, Rensselaer, New York, USA.

Received: 16 July 2014 Accepted: 10 October 2014

Published: 30 October 2014

\section{References}

1. USEIA: Annual Energy Outlook 2013. Washington, DC: United States Energy Information Administration; 2013 [http://www.eia.gov/forecasts/aeo/pdf/ 0383 (2013).pdf]

2. USEIA: Annual Energy Outlook 2012. Washington, DC: United States Energy Information Administration; 2012 [http://www.eia.gov/forecasts/aeo/pdf/ 0383 (2012).pdf]

3. USEIA: Glossary of Terms. Washington, DC: United States Energy Information Administration; 2014 [http://www.eia.gov/tools/glossary/]

4. Finkel ML, Law A: The rush to drill for natural gas: a public health cautionary tale. Am J Public Health 2011, 101:784-785.

5. Colborn T, Kwiatkowski C, Schultz K, Bachran M: Natural gas operations from a public health perspective. Hum Ecol Risk Assess Int J 2011, 17:1039-1056.

6. Witter RZ, McKenzie L, Stinson KE, Scott K, Newman LS, Adgate J: The use of health impact assessment for a community undergoing natural gas development. Am J Public Health 2013, 103:1002-1010.

7. Adgate $\mathrm{JL}$, Goldstein BD, McKenzie LM: Potential public health hazards, exposures and health effects from unconventional natural gas development. Environ Sci Technol. in press.

8. Jackson RB, Vengosh V, Darrah TH, Warner NR, Down A, Poreda RJ, Osborn SG, Zhao K, Karr JD: Increased stray gas abundance in a subset of drinking water wells near Marcellus shale gas extraction. Proc Nat Acad Sci 2013, 110:11250-11255.

9. Brown VJ: Radionuclides in fracking wastewater: managing a toxic blend. Environ Health Perspect 2014, 122:A50-A55.

10. Colborn T, Schultz K, Herrick L, Kwiatkowski C: An exploratory study of air quality near natural gas operations. Hum Ecol Risk Assess Int J 2013, 20:86-105.

11. McKenzie LM, Witter RZ, Newman LS, Adgate JL: Human health risk assessment of air emissions from development of unconventional natural gas resources. Sci Total Environ 2012, 424:79-87.

12. Shonkoff SB, Hays J, Finkel ML: Environmental public health dimensions of shale and tight gas development. Environ Health Perspect. in press.

13. Skone TJ, Littlefield J, Marriott J: Life Cycle Greenhouse Gas Inventory of Natural Gas Extraction, Delivery and Electricity Production. Pittsburgh, PA: United States Department of Energy, National Energy Technology Laboratory; 2011

14. Gilman JB, Lerner BM, Kuster WC, Gouw JA: Source signature of volatile organic compounds from oil and natural gas operations in northeastern Colorado. Environ Sci Technol 2013, 47:1297-1305.

15. Field RA, Soltis J, Murphy S: Air quality concerns of unconventional oil and natural gas production. Environ Sci Process Impacts 2014, 16:954-969.
16. Moore CW, Zielinska B, Petron G, Jackson RB: Air impacts of increased natural gas acquisition, processing, and use: a critical review. Environ $\mathrm{SC}$ Technol. in press.

17. Jiang M, Griffin WM, Hendrickson C, Jaramillo P, VanBriesen J, Venkatesh A: Life cycle greenhouse gas emissions of Marcellus shale gas. Environ Res Lett 2011, 6:034014.

18. Allen DT, Torres VM, Thomas J, Sullivan DW, Harrison M, Hendler A, Herndon SC, Kolb CE, Fraser MP, Hill AD, Lamb BK, Miskimins J, Sawyer RF, Seinfeld $\mathrm{JH}$ : Measurements of methane emissions at natural gas production sites in the United States. Proc Nat Acad Sci 2013, 110:17768-17773.

19. Schnell RC, Oltmans SJ, Neely RR, Endres MS, Molenar JV, White AB: Rapid photochemical production of ozone at high concentrations in a rural site during winter. Nat Geosci 2009, 2:120-122.

20. Witter R, McKenzie L, Towle M, Stonson K, Scott K, Newman L, Adgate J: Health Impact Assessment for Battlement Mesa, Garfield County Colorado. Aurora, CO: Colorado School of Public Health; 2010.

21. Bunch AG, Perry CS, Abraham L, Wikoff DS, Tachovsky JA, Hixon JG, Urban $J D$, Harris MA, Haws LC: Evaluation of impact of shale gas operations in the Barnett Shale region on volatile organic compounds in air and potential human health risks. Sci Total Environ 2013, 468:832-842.

22. Morris J, Song L, Hasemyer D: Big Oil, Bad Air: Fracking the Eagle Ford Shale of South Texas. Washington, DC: Center for Public Integrity; 2014.

23. Goldstein BD, Brooks BW, Cohen SD, Gates AE, Honeycutt ME, Morris JB, Orme-Zavaleta J, Snawder J: The role of toxicological science in meeting the challenges and opportunities of hydraulic fracturing. Toxicol Sci 2014, 139:271-283.

24. McKenzie LM, Guo R, Witter RZ, Savitz DA, Newman LS, Adgate JL: Birth outcomes and maternal residential proximity to natural gas development in rural Colorado. Environ Health Perspect. in press.

25. Brown $D$, Weinberger $B$, Lewis $C$, Bonaparte $H$ : Understanding exposure from natural gas drilling puts current air standards to the test. Rev Environ Health. in press.

26. Fuller CH, Brugge D, Williams PL, Mittleman MA, Lane K, Durant JL, Spengler JD: Indoor and outdoor measurements of particle number concentration in near-highway homes. J Expo Sci Environ Epidemio/ 2013, 23:506-512.

27. Rogers H: Shale gas-the unfolding story. Oxford Rev Econ Poly 2011, 27:117-143.

28. Steinzor N, Subra W, Sumi L: Investigating links between shale gas development and health impacts through a community survey project in Pennsylvania. New Solutions 2013, 23:55-83.

29. Eapi GR, Sabnis MS, Sattler ML: Mobile measurement of methane and hydrogen sulfide at natural gas production site fence lines in the Texas Barnett Shale. J Air Waste Manag Assoc. in press.

30. Kargbo DM, Wilhelm RG, Campbell DJ: Natural gas plays in the Marcellus Shale: challenges and potential opportunities. Environ Sci Technol 2010, 44:5679-5684.

31. Beusse R, Dunlap C, Good K, Hauck E, McGhee-Lenart R, Narimatsu J: EPA Needs to Improve Air Emissions Data for the Oil and Natural Gas Production Sector. Washington, DC: Office of the Inspector General of the United States, Environmental Protection Agency, Report 13-P-0161; 2013.

32. Rappenglueck B, Ackermann L, Alvarez S, Golovko J, Buhr M, Field R, Slotis J, Montague DC, Hauze B, Adamson S, Risch D, Wilkerson G, Bush D, Stoeckenius R, Keslar C: Strong wintertime ozone events in the Upper Green River Basin, Wyoming. Atmos Chem Phys 2014, 14:4909-4934.

33. Oltmans S, Schnell RC, Johnson B, Petron G, Mefford T, Nelly RN: Anatomy of wintertime ozone associated with oil and natural gas extraction activity in Wyoming and Utah. Elementa 2014. in press.

34. Swarthout RF, Russo RS, Zhou Y, Hart AH, Sive BC: Volatile organic compound distributions during the NACHTT campaign at the Boulder Atmospheric Observatory: influence of urban and natural gas sources. J Geophys Res-Atmos 2013, 118:10614-10637.

35. Petron G, Frost G, Miller BR, Hirsch Al, Montzka SA, Karion A, Trainer M, Sweeney C, Andrews AE, Miller L, Kofler J, Bar-llan A, Dlugokencky EJ, Patrick L, Moore CT Jr, Ryerson TB, Siso C, Kolodzey W, Lang PM, Conway T, Novelli P, Masarie K, Hall B, Guenther D, Kitzis D, Miller J, Wlesh D, Wolfe D, Neff W, Tans P: Hydrocarbon emissions characterization in the Colorado Front Range: a pilot study. J Geophys Res-Atmos 2012, 117:1-19.

36. Helmig D, Thompson CR, Evans J, Boylan P, Hueber J, Park JH: Highly elevated atmospheric levels of volatile organic compounds in the Uintah Basin, Utah. Environ Sci Technol. in press.

37. Peischl J, Ryerson TB, Brioude J, Aikin KC, Andrews AE, Atlas E: Quantifying sources of methane using light alkanes in the Los Angeles basin, California. J Geophys Res-Atmos 2013, 118:4974-4990. 
38. Karion A, Sweeney C, Petron G, Frost G, Hardesty R, Kofler J, Miller BR, Newberger T, Wolter S, Banta R, Brewer A, Dlugokencky E, Lang P, Montzka SA, Schnell R, Tans P, Trainer M, Zamora R, Conley S: Methane emissions estimate from airborne measurements over a western United States natural gas field. Geophys Res Lett 2013, 40:4393-4397.

39. Litovitz A, Curtright A, Abramzon S, Burger N, Samaras C: Estimation of regional air-quality damages from Marcellus Shale natural gas extraction in Pennsylvania. Environ Res Lett 2013, 8:014017.

40. Zielinska B, Fujita E, Campbell D: Monitoring of Emissions from Barnett Shale Natural Gas Production Facilities for Population Exposure Assessment. Reno, NV: Desert Research Institute; 2010.

41. Levi MA: Comment on "Hydrocarbon emissions characterization in the Colorado Front Range: a pilot study" by Gabrielle Petron et al. J Geophys Res Atmos 2012, 117:D21203.

42. Shepard PM, Northridge ME, Parkesh S, Stover G: Advancing environmental justice through community-based participatory research. Environ Health Perspect 2002, 110:139.

43. Minkler M: Linking science and policy through community-based participatory research to study and address health disparities. Am J Public Health 2010, 100:81-87

44. Keeler GJ, Dvonch T, Yip FY, Parker EA, Israel BA, Marsik FJ, Morishita M, Barres JA, Robins TG, Brakefield-Caldwell W, Sam M: Assessment of personal and community-level exposures to particulate matter among children with asthma in Detroit, Michigan. Environ Health Perspect 2002, 110:173-181.

45. Hobson J, Fishman S: Quality Assurance Program Plan for the "Bucket Brigade" Community Air Sampling Pilot Project, Approved by EPA Region IX and Contra Costa County Health Services; 1998.

46. Plate MC: Region 9 Summary of Quality Assurance Planning for the "Bucket Brigade" Community Air Sampling Project, Contra Costa County, California. San Francisco, CA: United States Environmental Protection Agency Region Nine; 2001.

47. Hobson J, Fishman S: In Kind Donation of Analysis to the Contra Costa Bucket Brigade. San Francisco, CA: Letter from Project Coordinator, Contra Costa County Health Services to Brenda Bettencourt, Lab Director, EPA Region IX Laboratory; 1998.

48. O'Rourke D, Macey GP: Community environmental policing: assessing new strategies for public participation in environmental regulation. J Pol'y Analysis Manag 2003, 22:383-414.

49. Larson D, Breech R, Hendricks J, Chernaik M, Mall A, Smith F: Gassed: Citizen Investigation of Toxic Air Pollution from Natural Gas Development. El Cerrito, CA: Global Community Monitor; 2011.

50. NDEP: Summa Canister Sampling. Carson City, NV: State of Nevada Division of Environmental Protection; 2011 [http://www.ndep.nv.gov/fallon/summa/pdf]

51. USEPA: Laboratory Case Narrative, Case Number R98X02. Richmond, CA: United States Environmental Protection Agency Region IX; Nov. 1998.

52. USEPA: Laboratory Case Narrative, Case Number R99X02. Richmond, CA: United States Environmental Protection Agency Region IX; Jan. 1999.

53. USEPA: Laboratory Case Narrative, Case Number R99X02. Richmond, CA: United States Environmental Protection Agency Region IX; May 1999.

54. USEPA: Laboratory Case Narrative, Case Number R99X02. Richmond, CA: United States Environmental Protection Agency Region IX; Jun. 1999.

55. Darrow LA, Klein M, Sarnat JA, Mulholland JA, Strickland MJ, Sarnat SE, Russell AG, Tolbert PE: The use of alternative pollutant metrics in timeseries studies of ambient air pollution and respiratory emergency department visits. J Exp Sci Environ Epi 2011, 21:10-19.

56. Delfino R, Zeiger RS, Seltzer JM, Street DH, McLaren CE: Association of asthma symptoms with peak particulate air pollution and effect modification by anti-inflammatory medication use. Environ Health Perspect 2002, 110:A607-A617.

57. Mills NL, Tornqvist H, Gonzalez MC, Vink E, Robinson SD, Soderberg S, Boon NA, Donaldson K, Sandstrom T, Blomberg A, Newby DE: Ischemic and thrombotic effects of dilute diesel-exhaust inhalation in men with coronary heart disease. N Engl J Med 2007, 357:1075-1082.

58. USATSDR: Toxicological Profile for Hydrogen Sulfide. Atlanta, GA: United States Agency for Toxic Substances and Disease Registry Division of Toxicology and Environmental Medicine/Applied Toxicology Branch; 2006.

59. USATSDR: Toxicological Profile for Formaldehyde. Atlanta, GA: United States Agency for Toxic Substances and Disease Registry Division of Toxicology and Environmental Medicine/Applied Toxicology Branch; 1999.

60. USATSDR: Toxicological Profile for Benzene. Atlanta, GA: United States Agency for Toxic Substances and Disease Registry Division of Toxicology and Environmental Medicine/Applied Toxicology Branch; 2007.
61. Testa BM: Home on the shales. Mech Eng 2013, 135:30-35.

62. USEPA: Oil and natural gas sector: new source performance standards and national emission standards for hazardous air pollutants reviews. Fed Reg 2014, 77:49490-49600. Washington, DC: United States Environmental Protection Agency.

63. Vlaanderen J, Lan Q, Kromhout H, Rothman N, Vermeulen R: Occupational benzene exposure and the risk of lymphoma subtypes: a meta-analysis of cohort studies incorporating three study quality dimensions. Environ Health Perspect 2011, 119:159-167.

64. Smith MT: Advances in understanding benzene health effects and susceptibility. Ann Rev Public Health 2010, 31:133-148.

65. Lupo PJ, Symanski E, Waller DK, Chan W, Langlois PH, Canfield MA, Mitchell LE: Maternal exposure to ambient levels of benzene and neural tube defects among offspring: Texas, 1999-2004. Environ Health Perspect 2011, 119:397-402.

66. Gross SA, Avens HJ, Banducci AM, Sahmel J, Panko JM, Tvermoes BE: Analysis of BTEX groundwater concentrations from surface spills associated with hydraulic fracturing operations. J Air Waste Manag Assoc 2013, 63:424-432.

67. Wolf Eagle Environmental: Town of Dish, Texas Ambient Air Monitoring Analysis Final Report. Flower Mound, TX: Wolf Eagle Environmental; 2009 [http://townofdish.com/objects/DISH___final_report_revised.pdf].

68. D'Andrea MA, FACRO, Reddy GK: Health effects of benzene exposure among children following a flaring incident at the British Petroleum refinery in Texas City. Pediatr Hematol Oncol 2014, 31:1-10.

69. USEPA: Natural Gas-Fired Reciprocating Engines, Volume AP-42 Section 3.2. Washington, DC: United States Environmental Protection Agency; 2000 [http://www.epa.gov/ttn/chief/ap42/ch03/final/c03s02.pdf]

70. Ingraffea AR, Wells MT, Santoro RL, Shonkoff SBC: Assessment and risk analysis of casing and cement impairment in oil and gas wells in Pennsylvania, 2000-2012. Proc Nat Acad Sci. in press.

71. Barnett Shale Energy Education Council: Air Quality and the Barnett Shale. Fort Worth, TX; 2011 [http://www.bseec.org/content/air-quality-and-barnettshale]

72. Eastern Research Group: City of Fort Worth Natural Gas Air Quality Study. Morrisville, NC; 2011 [http://fortworthtexas.gov/uploadedFiles/Gas_Wells/ AirQualityStudy_final.pdf]

73. USATSDR: Report on Carcinogens, Twelfth Edition. Research Triangle Park, NC: United States Agency for Toxic Substances and Disease Registry, National Toxicology Program; 2011.

74. Kim K, Jahan SA, Lee J: Exposure to formaldehyde and its potential human health hazards. J Environ Sci Health Part C Environ Carcinog Ecotoxicol Rev 2011, 29:277-299.

75. McGwin G, Lienert J, Kennedy J: Formaldehyde exposure and asthma in children: a systematic review. Environ Health Perspect 2010, 118(3):313-317.

76. Wolkoff $P$, Nielsen GD: Organic compounds in indoor air-their relevance for perceived indoor air quality. Atmos Environ 2001, 35:4407-4417.

77. USEPA: Integrated Risk Information System, n-Hexane. Washington, DC: United States Environmental Protection Agency; 2005.

78. Legator MS, Morris DL, Philips DL, Singleton CR: Health effects from chronic low-level exposure to hydrogen sulfide. Arch Environ Health 2001, 56:123-131.

79. USATSDR: Addendum to the Toxicological Profile for Hydrogen Sulfide. Atlanta, GA: United States Agency for Toxic Substances and Disease Registry, Division of Toxicology and Environmental Medicine/Applied Toxicology Branch; 2012.

80. CDPHE: Air Emissions Case Study Related to Oil and Gas Development in Erie. Denver, CO: Colorado Department of Public Health and Environment; 2012.

81. ADEQ: Emissions Inventory and Ambient Air Monitoring of Natural Gas Production in the Fayetteville Shale Region. North Little Rock, AR: Arkansas Department of Environmental Quality; 2011.

82. PADEP: Southwestern Pennsylvania Marcellus Shale Short-Term Ambient Air Sampling. Harrisburg, PA: Pennsylvania Department of Environmental Protection, Bureau of Air Quality; 2010.

83. Sexton $\mathrm{K}$, Westberg $\mathrm{H}$ : Nonmethane hydrocarbon composition of urban and rural atmospheres. Atmos Environ 1984, 18:1125-1132.

84. Carpenter DO, Arcaro K, Spink DC: Understanding the human health effects of chemical mixtures. Environ Health Perspect 2002, 110:25-42.

85. Lan Q, Zhang L, Li G, Vermeulen R, Weinberg RS, Dosemeci M, Rappaport SM, Shen M, Alter BP, Wu Y, Kopp W, Waidyanatha S, Rabkin C, Guo W, Chanock S, Hayes RB, Linet M, Kim S, Yin S, Rotham N, Smith MT: Hematotoxicity in workers exposed to low levels of benzene. Sci 2004, 306:1774-1776. 
86. Vandenberg LN, Colborn T, Hayes TB, Heindel JJ, Jacobs DR, Lee DH, Shioda T, Soto AM, vom Saal FS, Welshons WW, Zoeller RT, Myers JP: Hormones and endocrine-disrupting chemicals: low-dose effects and nonmonotonic dose responses. Endocrinol Rev 2012, 33:378-455.

87. Macey GP: The architecture of ignorance. Utah L Rev 2013, 2013:1627-1685.

88. Carlin DJ, Rider CV, Woychik R, Birnbaum LS: Unraveling the health effects of environmental mixtures: an NIEHS priority. Environ Health Perspect 2013, 121:6-8.

doi:10.1186/1476-069X-13-82

Cite this article as: Macey et al: Air concentrations of volatile compounds near oil and gas production: a community-based exploratory study.

Environmental Health 2014 13:82.

\section{Submit your next manuscript to BioMed Central and take full advantage of:}

- Convenient online submission

- Thorough peer review

- No space constraints or color figure charges

- Immediate publication on acceptance

- Inclusion in PubMed, CAS, Scopus and Google Scholar

- Research which is freely available for redistribution 